\title{
SEED AGENCIES FOR GRASSLANDS' CULTIVARS
}

\section{J.A. Lancashire}

The seed agency system was set up in New Zealand to inject some new life into the industry. Over the past 30 years the New Zealand Herbage Seeds Industry has been in a no-growth phase: it has not expanded; the amount of certified seed has been static, if not declining; exports have stayed at the same level in terms of percentage of total exports; the-amount of pasture renewal has stayed at 2-3\% of the total pasture area. During this time there was little promotion of the different cultivars of grass seed, presumably because individual companies were reluctant to spend money on advertising which would not benefit them specifically. By bringing in a system whereby individual companies within New Zealand have the responsibility for individual cultivars, expenditure on promotion is directly recoupable by the company doing the promoting. Furthermore, planned marketing with amounts of seed grown being linked into projected markets which have been created or developed both here and overseas, is possible. Diversification within the industry is also possible; we are now handling far more cultivars than before, and will be able to cope with the increasing number of specialist cultivars being produced by Grasslands. For instance, we have a breeding programme on Poa annua; we're looking at other 'weeds', such as plantains, which have a place in terms of agricultural productivity; chicory has been considered to be a weed of cereal crops in the past, particularly in Australia, but is probably one of the best looking forages to come out of the New Zealand Herbage Seeds industry in some years; Raki paspalum, which does not even grow in Canterbury, has a very large potential market overseas. Thus there is a wealth of material which would be difficult to handle in any way other than by the Head Licensee system which has been put into place.

The Head Licensee system was proposed and discussed during 1984 and 1985 by the Seed Promotion Council. The latter is an industry body set up to promote the New Zealand seed industry both within New Zealand and overseas. The Council put together a proposal for the Head Licensee system and an agreement was made between the DSIR, the Agricultural Merchants Federation (AMF) and Federated Farmers. The agreement was signed at the end-of 1985 by the Minister of Science and representatives of the participating bodies. The system is for Grasslands cultivars only. Private companies with their own breeding programmes "own" any cultivar they produce and, having done their own research and development, also do their own marketing.

The head licensee system works in the following way:

Grasslands' breeding programmes produce new cultivars. In April each year a certain number (this year it will probably be six) are submitted to the AMF with accompanying documentation, often running to 20 or 30 pages of data on seed production, agronomic performance, and national and international evaluation. The 
AMF convene a sub-committee, generally the New Zealand Plant Breeding and -Research Association (PBRA). They meet as representatives of the industry, and they make recommendations. They call for applications for Head Licenseeships through the AMF and through various other groups including Federated Farmers. In the past it is possible that information has not been getting out as widely as it should have been; this year steps have been taken to ensure that information on cultivars coming up for licence is much more widely available. Applications in response to the advertisements are passed from the AMF to the PBRA. They discuss the advantages and disadvantages of the applications and make recommendations to Grasslands Division through the AMF. Grasslands Division considers the recommendation and passes it to Federated Farmers who then have 30 days in which to give their views.

Choice of Head Licensee is based upon several criteria which include an ability to market and promote technical expertise, experience in handling different types of cultivar, and having a good reputation. There is always a lot of discussion about particular cases, but if agreement is reached, a provisional recommendation will be made and forwarded to the company concerned. They then have to submit a confidential marketing plan for the cultivar. The plan is examined and discussions occur between the cultivar's owners (the DSIR) and the recommended licensee. If the discussions prove satisfactory then the recommendation to proceed down the particular route of that company is made.

The follow-up process includes a very important annual review for each cultivar which takes place at the end of August. The review committee, comprising representatives from the various groups, reviews a report from the Head Licensee on progress on each cultivar. Non-performing Head Licensees run the risk of losing the cultivar:

The new system has not yet been in place for long enough to say whether or not it is going to result in a significant boost to the industry. However, since its beginning, nearly 20 cultivars 'have been licensed out to various Head Licensees. The cultivars include some that'were already in commerce, such as Maku Lotus, Matua Prairie grass and Pawera red clover, which were considered good enough (by AMF and Federated Farmers) to be brought under agency. control.

The current position is that Grasslands breeds cultivars; Challenge Seeds has agencies for nine, Hodder and Tolley (a division of Elders Pastoral) have four, Pyne, Gould Guinness have four, AgriCom New Zealand (previously the Hinds Agriculture Company) has two, the Cocksfoot Seed Growers Association has one, and the Marlborough Lucerne Growers Association has one. Thus there is a good spread across companies.

Some of the cultivars released already, and some that are coming up for release, are always going to be fairly small. That does not mean that they are not useful. If there is a market here or overseas it is important to fill it even though it may take only 10 or 15 growers to do 'so. There are some good, profitable, smalldemand cultivars in the system. Some, like Koha serradella, may have hardly any 
market in New Zealand at all as the areas for which it is suited (deep, acid sands) are few in this country. However, the plant has performed outstandingly well in a wide range of Australian sites, and that is where Hodder \& Tolley will be marketing initially.

Head licensees collect a royalty for each cultivar of $10 \%$ of the wholesale price. Of this, half goes to the Head Licensee for funding of promotion of the cultivar, and half goes back into Grasslands' breeding programme. The Seed Promotion Council, which has representatives from the AMF, Federated Farmers and DSIR, is funded by a levy on all certified cultivars going through the Seed Testing Station. The Council meets about four times a year, employs journalists to write about the industry and cultivars, and funds promotional trips to Australia and Europe and displays at large agricultural shows such as Mystery Creek.

A range of material is now in the system; six more cultivars will be put to AMF shortly; the system is starting to roll. The future' for the industry lies in having as many cultivars as possible with market potential. We must recognise that it is an international business. Survival depends upon having cultivars that are better than any others that are available on the international market. There is no doubt that there is a lot of pressure on traditional cultivars, particularly Huia white clover, but we do know (because part of our activity is to do international evaluations) that plants like Egmont and Sefton browntop are doing outstandingly well in recreational areas overseas (e.g., the United States and Britain). Thus there is potential for Head Licensees in overseas markets. 